\title{
Pengembangan Aplikasi Pengecekan Status Pembuatan KTP Elektronik
}

\author{
Asri Mulyani ${ }^{1}$, Annisa Atmanati ${ }^{2}$ \\ Jurnal Algoritma \\ Sekolah Tinggi Teknologi Garut \\ J1. Mayor Syamsu No.1 Jayaraga Garut 44151 Indonesia \\ Email: jurnal@itg.ac.id \\ 1'asrimulyani@itg.ac.id \\ 21606005@itg.ac.id
}

\begin{abstract}
Abstrak - KTP Elektoronik merupakan tanda untuk keterangan diri yang sah sebagai bukti kependudukan pada dasarnya pelayanan KTP telah ditetapkan sebagai standar pelayananoleh Kementrian Dalam Negeri. Permasalahan yang sering terjadi dalam pembuatan KTP Elektronik antara lain waktu pencetakan setelah perekaman menjadi lambat, penyebab keterlambatan tersebut yaitu tidak lengkapnya data atau dokumen persyaratan, contohnya seperti data keluarga yang tidak diperbaharui belum mempunyai surat keterangan pindah bagi yang pindah domisili, tidak sesuai antara data lahir dalam akta kelahiran dengan data kartu keluarga atau belum melakukan proses perpindahan basis data bagi perpindahan pemohon domisili, faktor tersebut akan menyebabkan proses pembuatan KTP Elektronik semakin lama dan membutuhkan waktu jangka panjang, sehingga peningkatan pelayanan dalam proses pembuatan KTP Elektronik sangat dibutuhkan akan tetapi belum menggunakan bantuan teknologi khususnya dalam proses pengecekan status pelayanan pembuatan KTP elektronik. Pada penelitian menggunakan metodologi Rational Unified Processing $(R U P)$ dengan tahapannya yakni inception, elaboration, construction, transition, aplikasi yang dibuat menggunakan software Tools Visual Studio Code dan untuk bahasa pemograman menggunakan Node $J S \&$ React Native. Hasil penelitian ini adalah pengembangan aplikasi pengecekan status pembuatan KTP Elektronik berbasis android dapat membantu khususnya pengguna masyarakat mempermudah pelayanan pengecekan status pembuatan KTP Elektronik dengan menggunakan smartphone.
\end{abstract}

Kata Kunci - Android; KTP Elektronik; Status.

\section{PENDAHULUAN}

KTP Elektoronik merupakan tanda untuk keterangan diri yang sah sebagai salah satu bukti kependudukan pada dasarnya pelayanan KTP telah ditetapkan sebagai standar pelayanan oleh Kementrian Dalam Negeri. Dalam pembuatan KTP tidak semua bisa berjalan dengan lancar karena adanya faktor kendala yang menyebabkan pembuatan KTP diantaranya keterbatasan staff yang bekerja di DISDUKCAPIL, ada juga kendala seperti tidak mempunyai kendaraan ataupun jarak yang jauh, pemohon memberikan data tidak lengkap serta terdapat kesalahan data yang menjadikan faktor permasalahan sendiri [1][2][3]. Dalam perkembangan juga kemajuan teknologi informasi yang sangat pesat serta bermacam-macam potensi dalam pemanfaatnya, sehingga membuka beberapa macam peluang sehingga memudahkan kinerja manusia, pemanfaatan teknologi informasi sudah banyak menembus beberapa bidang, dari bidang bisnis, pendidikan hingga pemerintahan [4]. Permasalahan yang sering terjadi dalam pembuatan KTP Elektronik antara lain waktu pencetakan setelah perekaman menjadi lambat, penyebab keterlambatan tersebut yaitu tidak lengkapnya data atau dokumen persyaratan, contohnya seperti data keluarga yang tidak diperbaharui belum mempunyai surat keterangan pindah bagi yang pindah domisili, tidak sesuai antara data lahir dalam akta kelahiran dengan data kartu keluarga atau belum melakukan proses perpindahan basis data bagi perpindahan pemohon domisili, faktor 
tersebut akan menyebabkan proses pembuatan KTP Elektronik semakin lama dan membutuhkan waktu jangka panjang, sehingga peningkatan pelayanan dalam proses pembuatan KTP Elektronik sangat dibutuhkan akan tetapi belum menggunakan bantuan teknologi khususnya dalam proses pengecekan status pelayanan pembuatan KTP elektronik [5].

Penelitian meliputi beberapa dari penelitian sebelumnya yang menghasilkan keluaran aplikasi mengenai pembuatan KTP Elektronik, penelitian pertama berjudul "Aplikasi Formulir KTP Di Kantor Camat Rantau Utara Berbasis Android" aplikasi berbasis android ini bertujuan untuk dapat memberikan kemudahan khusnya bagi masyarakat dalam mengisi formulir KTP sehingga tanpa harus datang ke formulir permintaan kantor yang dapat diisi dimana pun dengan menggunakan smartphone juga mempercepat proses layanan dan membuat kartu ID [6][7]. Penelitian rujukan kedua yang dengan judul "Sistem Informasi Pendaftran Pembuatan KTP Elektronik Di Dinas Kependudukan dan Pencatatn Sipil Kabupaten Kuantan Singingi" sistem informasi berbasis web ini memudahkan pemohon pendaftaran kartu tanda penduduk elektronik (KTP-el) untuk melaksanakan proses pendaftaran kemudian keuntungan dari sistem informasi berbasis web ini dapat mecegah antrian masyarakat yang ingin membuat KTP elektronik di Dinas Kependudukan dan Pencatatan Sipil [1]. Penelitian rujukan ketiga yang berjudul "Rancang Bangun Sistem Informasi Pendaftaran E-KTP Berbasis Web Study Kasus Kecamatan Gadingrejo" dengan adanya sistem informasi pelayanan maka memudahkan warga masyarakat dalam menangani administrasi kependudukan dan memperoleh informasi yang masyarakat butuhkan [8][9]. Penelitian rujukan keempat yang berjudul "Aplikasi Pembuatan E-KTP Pada Kabupaten Pringsewu" dengan adanya sistem informasi ini dapat mempermudah masyarakat dalam pembuatan kartu tanda penduduk secara online serta dengan pelaksanaan ini akan menunjang kinerja DISDUKCAPIL sehingga penyajian yang diberikan khususnya pada warga masyarakat akan semakin optimal [4]. Penelitian rujukan kelima yang berjudul "Aplikasi Data Kependudukan Berbasis Web di RT 04 RW 03 Kampung Karang Sari Desa Cihanjuang" dengan terciptanya layanan website yang dapat menghubungkan ke jaringan internet, sehingga sistem pelayanan akan dapat dengan mudah mendapatkan suatu informasi [10]. Demi menghasilkan buatan aplikasi yang berbeda dalam penelitian saat ini membahas tentang pengembangan aplikasi pengecekan status pembuatan KTP Elektronik berbasis android sehingga menjadi salah satu aplikasi yang bertujuan untuk mempermudah layanan masyarakat dalam membuat KTP Elektronik sehingga bisa memantau sampai dimana status pembuatan KTP Elektronik dari jarak jauh menggunakan smarthphone.

\section{METODE PENELITIAN}

Metode menggunakan Rational Unified Process (RUP) adalah salah satu metode yang dikembangkan dengan cara menggabungkan beberapa macam best practices yang ada dalam suatu industri pengembangan perangkat lunak [11][12].

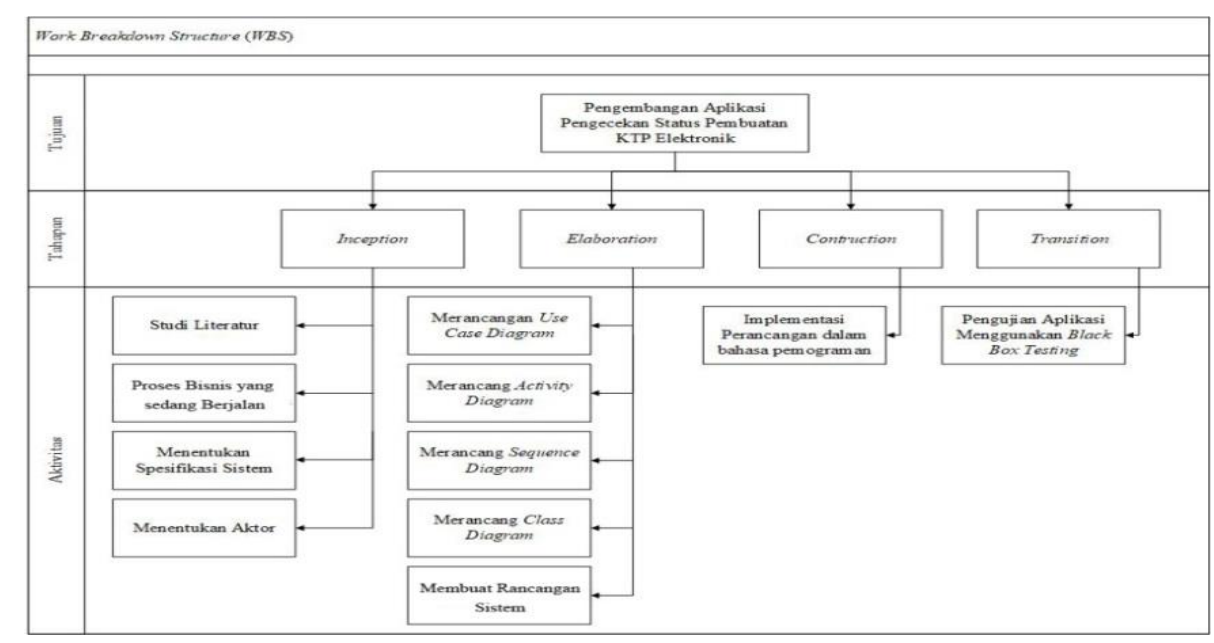

Gambar 1: Work Breakdown Structure

Berdasarkan WBS tersebut maka tahapannya adalah sebagaimana berikut: 
1) Tahapan yang pertama yakni inception merupakan tahapan persiapan yang dilakukan dalam merancang suatu sistem untuk menentukan identifikasi komponen-komponen yang diperlukan dengan cara melakukan studi dokumen atau pustaka pada penelitian sebelumnya serta observasi yang dilakukan;

2) Tahapan kedua adalah elaboration merupakan analisis lebih lanjut dari tahapan inception untuk menganalisis domain masalah, merancang dasar arsitektur, membangun suatu rencana proyek juga mengeleminasi resiko dari proyek;

3) Tahapan ketiga adalah construction adalah tahapan untuk mengintegrasikan segala nagian yang dibuat pada tahapan sebelumnya untuk menciptakan suatu software;

4) Tahapan keempat adalah transition pada tahapan ini akan dilakukan pengujian atau uji coba metode yang telah dibangun, pengetesan ini dilakukan dengan cara menggunakan black-box testing.

\section{HASIL DAN PEMBAHASAN}

Rancangan yang dibuat dalam pengembangan aplikasi pengecekan status pembuatan KTP elektronik berbasis android dengan menggunakan metodologi Rational Unified Processing (RUP). Berikut adalah hasil dari pengkajian dalam menciptakan suatu aplikasi dengan tahapan $R U P$ diantaranya:

1) Inception

Berikut adalah kegiatan dari tahap concept, sebagai berikut:

a. Studi literatur

Untuk melakukan penelitian perlu dilakukan suatu penyusunan yang sistematis agarvbisa memudahkan strategi yang akan diambil. Demikian yang di lakukan penulis dalam mengumpulkan data, strategi yang terpenting adalah melakukan studi literatur pada buku dan jurnal.

b. Identifikasi Proses Bisnis yang Berjalan

Proses usaha yang berjalan pada pengembangan aplikasi pengecekan status pembuatan KTP elektronik berbasis android ini adalah sebagai berikut:

Tabel 1: Identifikasi Proses Bisnis yang Berjalan

\begin{tabular}{|c|c|c|}
\hline No & Aktivitas & $\begin{array}{l}\text { Deskripsi } \\
\end{array}$ \\
\hline 1. & Memilih menu daftar akun & $\begin{array}{l}\text { User memilih menu pendaftaran untuk } \\
\text { melakukan pendaftaran lalu sistem akan } \\
\text { menampilkan menu pendaftaran untuk } \\
\text { membuat akun. }\end{array}$ \\
\hline 2. & Login & $\begin{array}{l}\text { User membuka sistem, kemudian sistem } \\
\text { menampilkan menu login untuk pengguna } \\
\text { melakukan login. }\end{array}$ \\
\hline 3. & Memilih menu biodata & $\begin{array}{l}\text { User memilih menu biodata kemudian } \\
\text { sistem akan menampilkan menu biodata } \\
\text { untuk diakses kemudian pengguna mengisi } \\
\text { biodata secara lengkap. }\end{array}$ \\
\hline 4. & Memilih menu informasi pengajuan & $\begin{array}{l}\text { User memilih menu informasi pengajuan } \\
\text { untuk menanyakan pertanyaan apabila } \\
\text { terdapat kendala kemudian sistem akan } \\
\text { menampilkan menu informasi sesuai } \\
\text { pertanyaan user. }\end{array}$ \\
\hline 5. & Memilih menu pengecekan status & $\begin{array}{l}\text { User memilih menu pengecekan status } \\
\text { untuk melakukan pengecekan status } \\
\text { pindah domisili belum mempunyai KTP } \\
\text { elektronik kemudian sistem akan } \\
\text { menampilkan informasi status. }\end{array}$ \\
\hline 6. & Memilih menu logout & User mengakhiri oengaksesan sistem. \\
\hline
\end{tabular}


c. Menentukan Spesifikasi Sistem

Menentukan Spesifikasi Sistem merupakan tahapan yang akan menjelaskan tentang kebutuhankebutuhan pada perancangan aplikasi yang akan dibangun.

d. Menentukan Aktor

Dalam menentukan aktor ini memiliki tujuan untuk mengenali target dari pemakai yang akan mengikuti dalam sistem.

Tabel 2: Aktor yang Terlibat

\begin{tabular}{|c|c|}
\hline Aktor & Aktivitas \\
\hline Admin & $\begin{array}{l}\text { Melakukan login } \\
\text { Mengelola data - data yang terdapat dalam web seperti } \\
\text { menambahkan, menghapus, dan mengedit konten pada } \\
\text { sistem. }\end{array}$ \\
\hline User & $\begin{array}{l}\text { Memilih dan melihat informasi proses dan kendala } \\
\text { membuat baru } \\
\text { Memilih dan melihat informasi progress dan kendala } \\
\text { pindah domisili sebelum mempunyai KTP elektronik } \\
\text { baru. }\end{array}$ \\
\hline
\end{tabular}

2) Elaboration

Dalam tahapan elaboration terdapat beberapa aktivitas yang diantaranya sebagai berikut:

a. Use Case Diagram

Use case diagram menjelaskan hubungan antar satu ataupun lebih aktor pada aplikasi yang diciptakan.

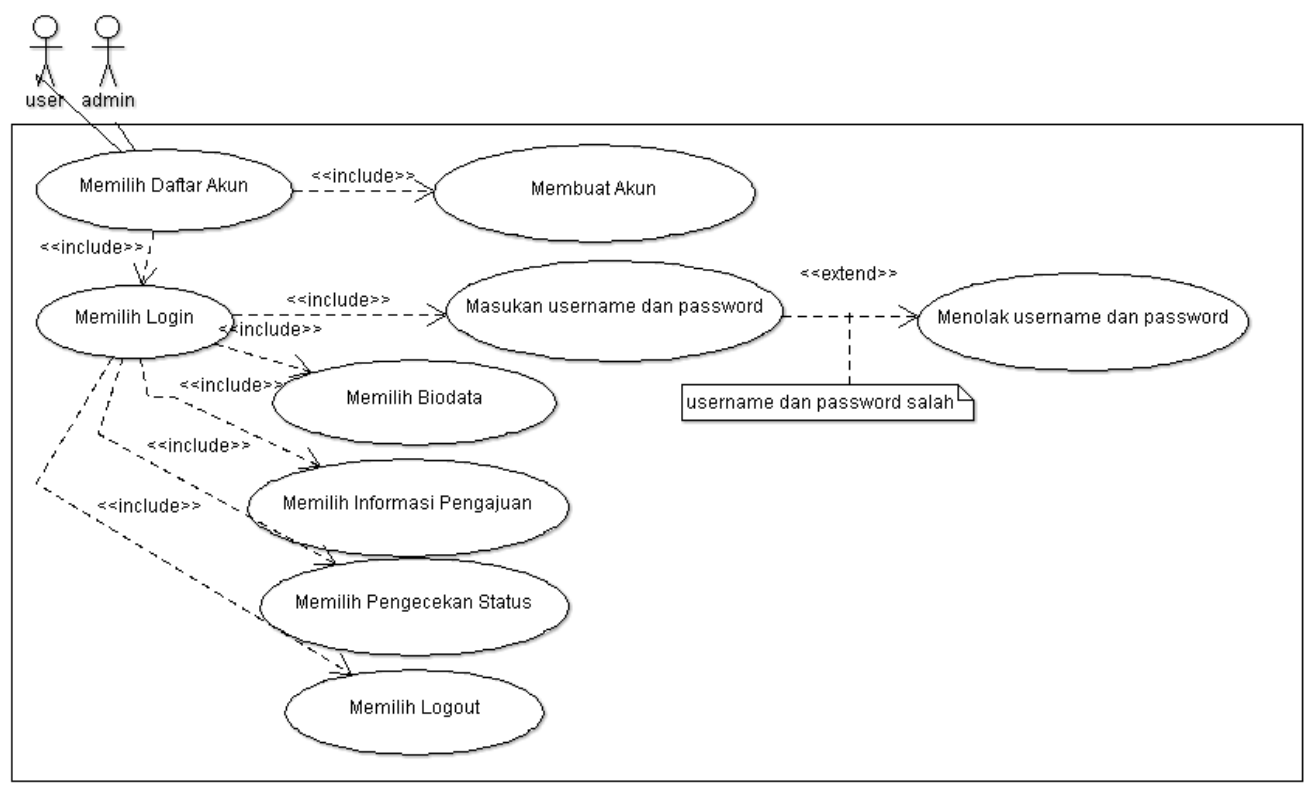

Gambar 2: Use Case Diagram

\section{b. Activity Diagram}

Activity diagram yakni cara untuk memodelkan pandangan perilaku dari sistem yang saling berhubungan. 

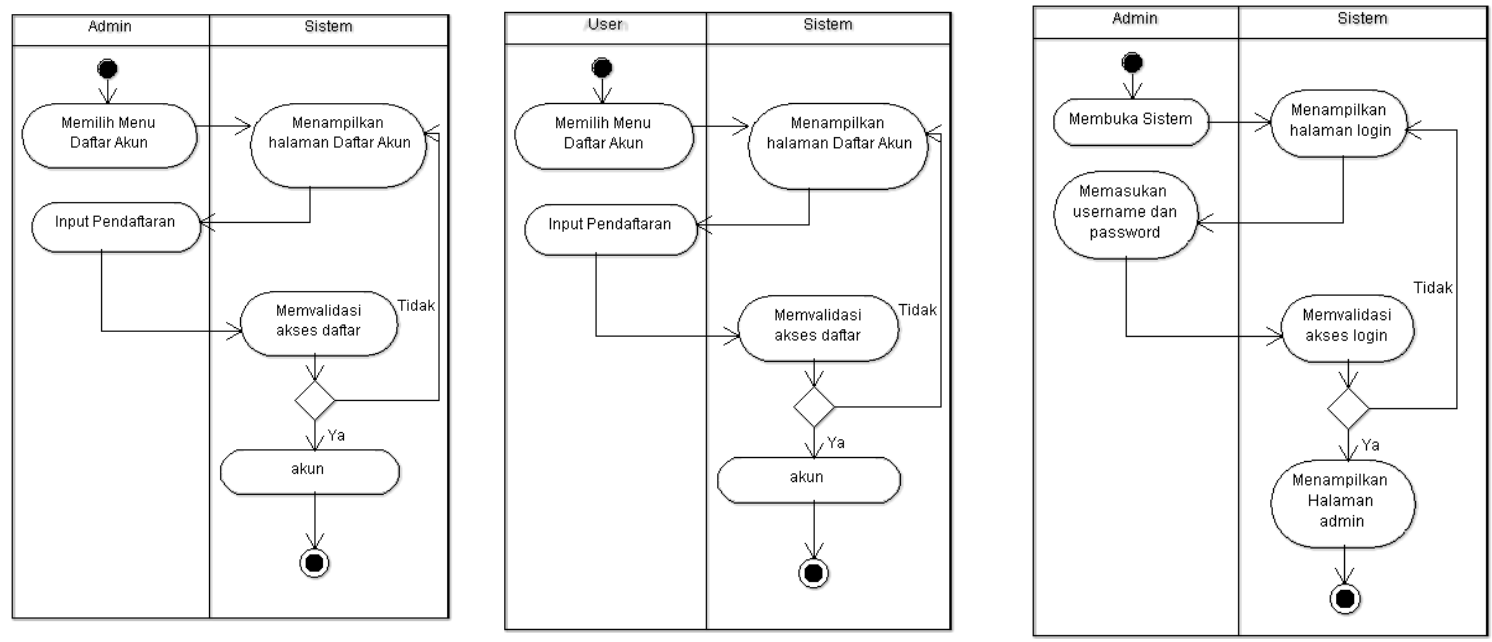

Gambar 3: Activity Diagram

c. Sequence Diagram

Sequence Diagram dapat digunakan dalam pemodelan pandangan pesan, kejadian juga kegiatan antara objek ataupun bagian dalam sistem

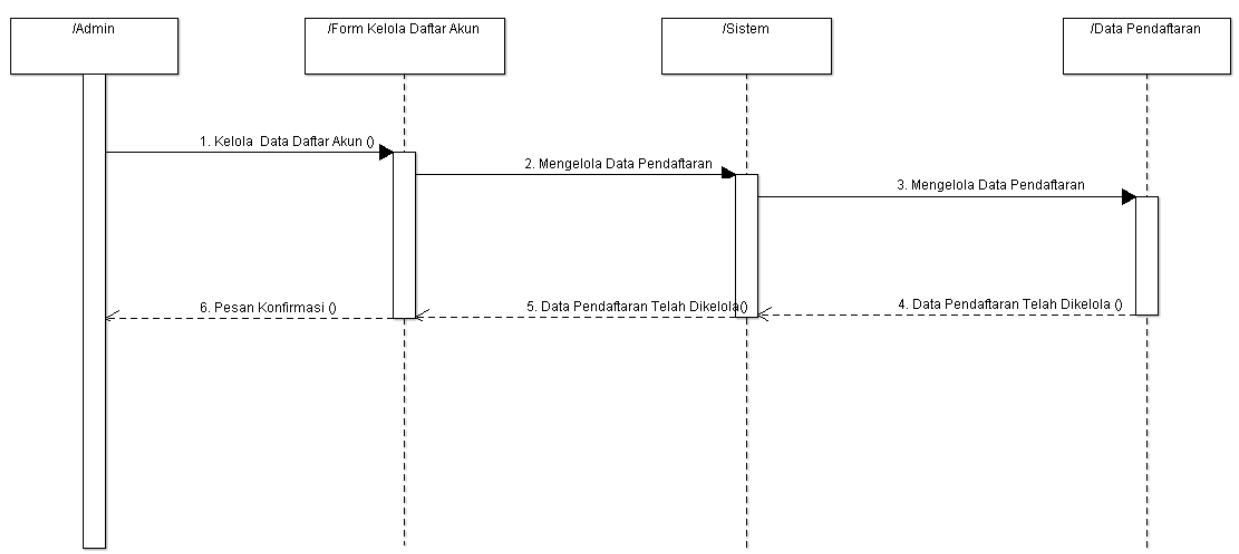

Gambar 4: Sequence Diagram

\section{d. Class Diagram}

Class Diagram dapat digunakan untuk memaparkan struktur statis sistem dan juga berperan sebagai daya dasar yang hampir setiap metode berorientasi objek, terlibat ke dalam $U M L$. 


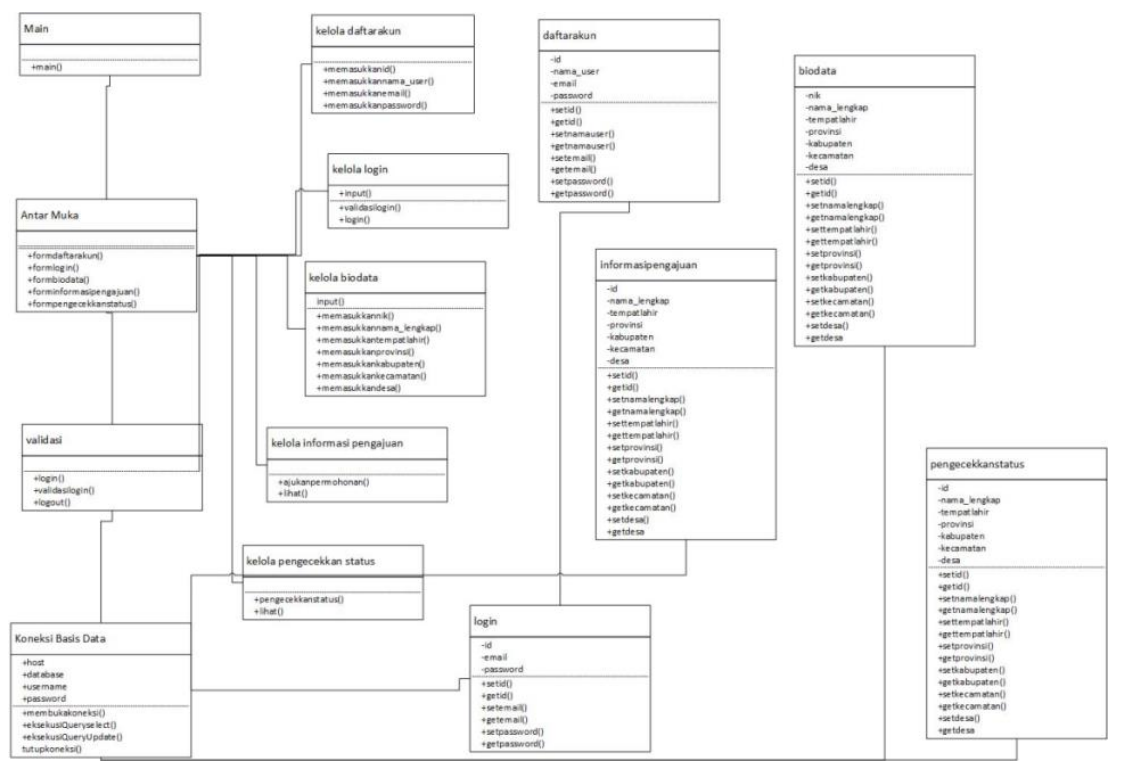

Gambar 5: Class Diagram

e. Membuat Rancangan Sistem

Rancangan sistem yang akan dibangun digambarkan dalam struktur menu seperti dibawah ini:

1. Struktur Menu

Struktur menu ialah alur dari suatu menu yang akan dilaksanakan, pada stuktur menu dapat melancarkan pengguna dalam menguasai perintah dan sasaran pada sistem yang telah diusulkan juga menampilkan alur informasi.

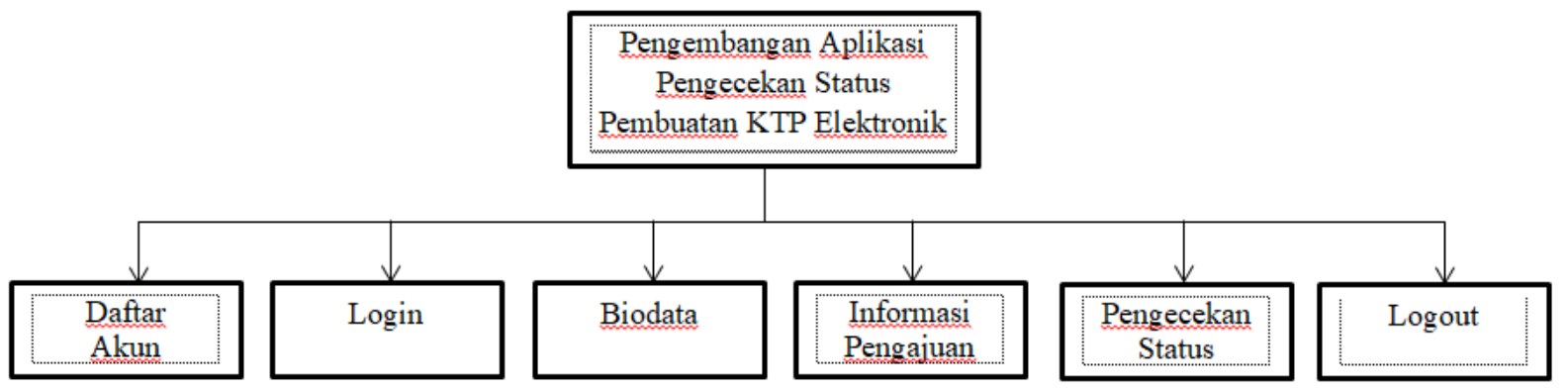

Gambar 6: Struktur Menu

2. Rancangan Layout

Berikut ini merupakan rancangan layout aplikasi pengecekan status pembuatan KTP Elektronik antara lain: 

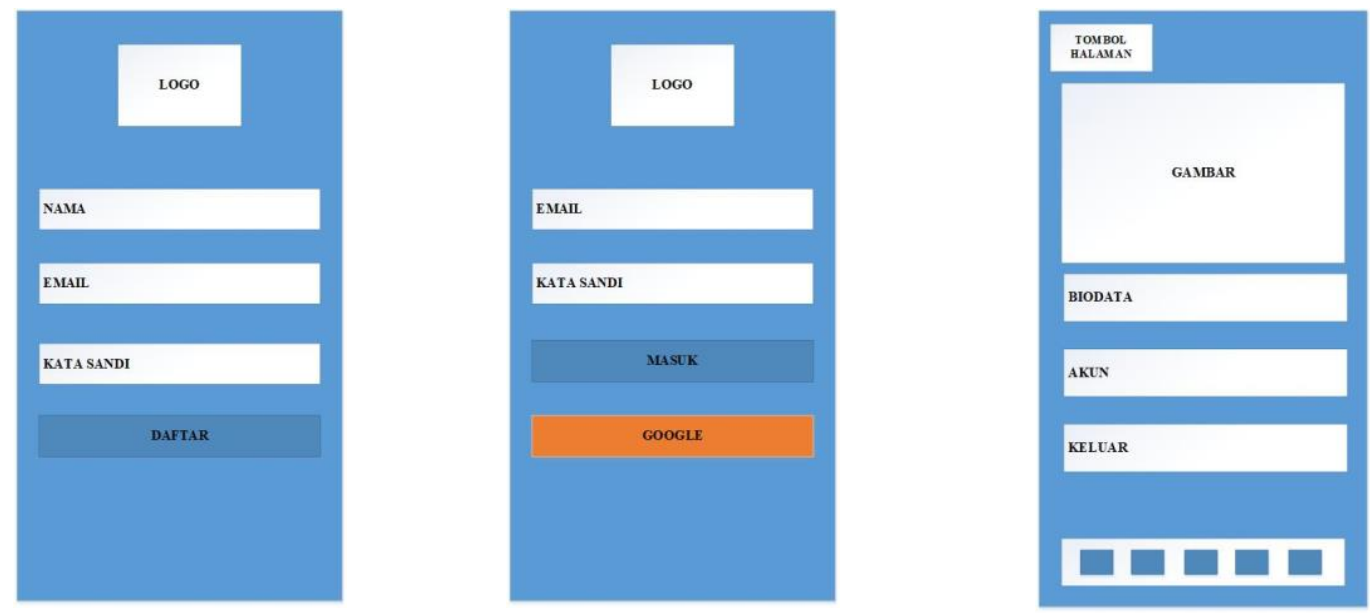

Gambar 7: Rancangan Layout

\section{3) Construction}

a. Perangkat Lunak yang Digunakan

b. Tampilan Sistem
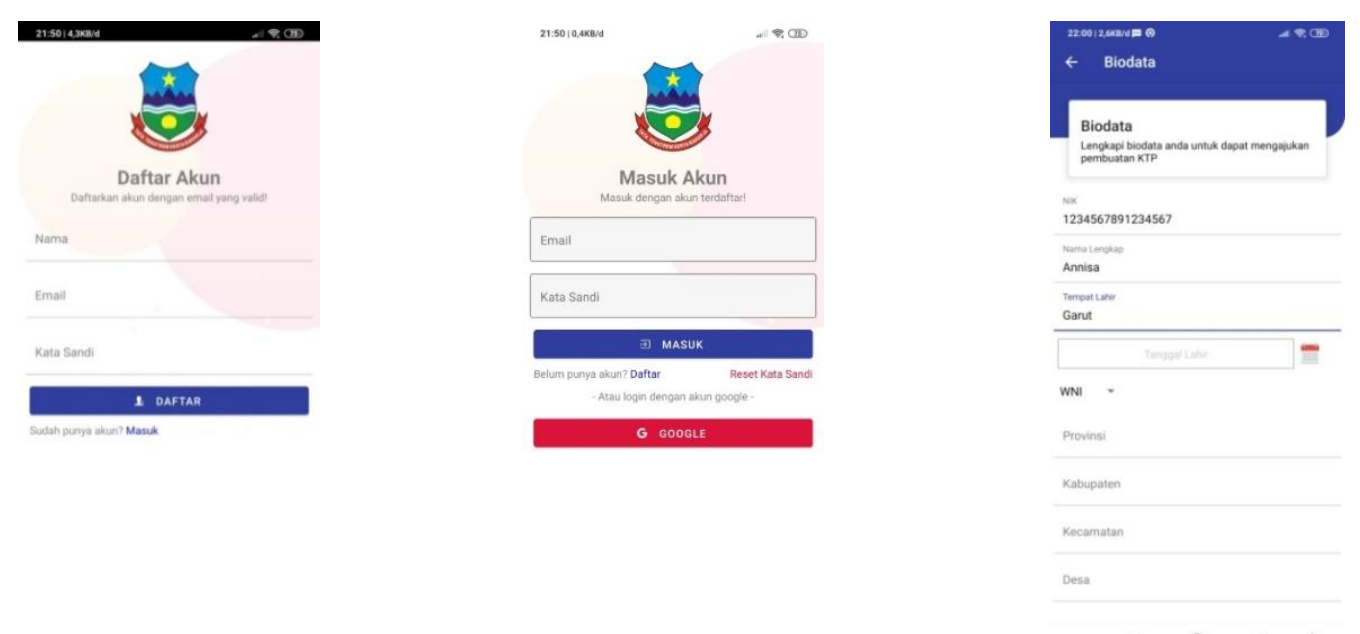

Gambar 8: Tampilan Sistem

\section{4) Transition}

Tahapan pengujian ini merupakan tahap untuk melakukan uji coba sistem dengan memakai pengujian black-box testing.

Tabel 3: Hasil Pengujian

\begin{tabular}{llll}
\hline \multicolumn{1}{c}{ Pengujian } & Bentuk Penguian & \multicolumn{1}{c}{$\begin{array}{c}\text { Hasil yang } \\
\text { diharapkan }\end{array}$} & Hasil Uji \\
\hline Form Pendaftaran & $\begin{array}{l}\text { User mengakses } \\
\text { menu pendaftaran } \\
\text { User } \text { mengakses } \\
\text { sistem pengecekan }\end{array}$ & $\begin{array}{l}\text { Menampilkan menu } \\
\text { pendaftaran } \\
\text { Menampilkan } \\
\text { halaman utama }\end{array}$ & Sukses \\
& Sukses
\end{tabular}




\begin{tabular}{|c|c|c|c|}
\hline Pengujian & Bentuk Penguian & $\begin{array}{r}\begin{array}{r}\text { Hasil yang } \\
\text { diharapkan }\end{array} \\
\end{array}$ & Hasil Uji \\
\hline & $\begin{array}{l}\text { status pembuatan } \\
\text { KTP elektronik }\end{array}$ & sistem & \\
\hline Form Biodata & $\begin{array}{l}\text { User mengakses } \\
\text { menu biodata }\end{array}$ & $\begin{array}{l}\text { Menampilkan } \\
\text { halaman biodata }\end{array}$ & Sukses \\
\hline $\begin{array}{l}\text { Form Informasi } \\
\text { Pengajuan }\end{array}$ & $\begin{array}{l}\text { User mengakses } \\
\text { menu informasi } \\
\text { pengajuan }\end{array}$ & $\begin{array}{l}\text { Menampilkan } \\
\text { informasi pengajuan }\end{array}$ & Sukses \\
\hline Form Pengecekan Status & $\begin{array}{l}\text { User mengakses } \\
\text { menu pengecekan } \\
\text { status }\end{array}$ & $\begin{array}{l}\text { Menampilkan } \\
\text { pemgecekan status } \\
\text { pembuatan KTP } \\
\text { elektronik }\end{array}$ & Sukses \\
\hline Logout & $\begin{array}{l}\text { User mengakses } \\
\text { menu logout }\end{array}$ & $\begin{array}{l}\text { Menampilkan } \\
\text { halaman logout }\end{array}$ & Sukses \\
\hline
\end{tabular}

\section{KESIMPULAN DAN SARAN}

\section{A. Kesimpulan}

Pada hasil dari pengkajian tentang aplikasi pengecekan status pembuatan KTP Elektronik berbasis android maka dapat disimpulkan:

1) Aplikasi pengecekan status pembuatan KTP Elektronik membantu pengguna khususnya masyarakat, untuk mempermudah masyarakat dalam pengecekan status pembuatan KTP elektronik agar bisa memantau proses pembuatan KTP Elektronik dari jarak jauh dengan menggunakan android, karena aplikasi dilengkapi dengan fitur:

a. Informasi pengajuan untuk melihat informasi kendala pembuatan KTP Elektronik baru serta solusi;

b. Pengecekan status untuk melihat informasi status pembuatan KTP Elektronik.

2) Permasalahan yang sering terjadi dalam pembuatan KTP Elektronik antara lain waktu pencetakan setelah perekaman menjadi lambat, proses pembuatan KTP Elektronik semakin lama dan membutuhkan waktu jangka panjang, sehingga peningkatan pelayanan dalam proses pembuatan KTP Elektronik sangat dibutuhkan, maka aplikasi pengecekan status pembuatan KTP Elektronik berbasis android ini untuk membantu masyarakat dalam pembuatan KTP Elektronik.

\section{B. Saran}

Mengenai saran dalam penyusunan laporan skripsi ini diantaranya:

1) Aplikasi dapat dikembangkan dengan melengkapi sistem sampai dengan percetakan KTP Elektronik.

2) Penting adanya pemeliharaan sistem dan penyempurnaannya secara berkala kemudian diperlukannya pertimbangan terhadap peluang pengembangan ulang sistem yang telah dirancang.

\section{DAFTAR PUSTAKA}

[1] R. Asmara and D. Saputra, "Sistem Informasi Pendaftaran Pembuatan KTP Elektronik Di Dinas Kependudukan Dan Pencatatan Sipil Kabupaten Kuantan Singingi.," J-Click, vol. 6, no. 2, pp. 201207, 2019.

[2] A. H. M. Syihab, "TINGKAT KEPUASANMASYARAKAT TERHADAP PELAYANAN KTP-el DI DINAS KEPENDUDUKAN DAN PENCATATAN SIPIL KECAMATAN TUBAN KABUPATEN TUBAN," Fak. Ilmu Sos. dan Ilmu Polit., vol. 3, no. 1, pp. 1-9, 2017.

[3] E. Wijayanti and A. Sindar, "Implementasi Analytical Hierarchy Process Dalam Menentukan Tingkat Kepuasan Pelayanan E-Ktp," J. Nas. Komputasi dan Teknol. Inf., 2018. 
[4] A. Zulkarnain, "Sistem Informasi Pelayanan Kependudukan Berbasis Web dan Sms Gateway Population Service Information System," e-Proceeding Appl. Sci., vol. 2, no. 3, pp. 966-973, 2016.

[5] Suendri, "Implementasi Diagram UML (Unified Modelling Language) Pada Perancangan Sistem Informasi Remunerasi Dosen Dengan Database Oracle (Studi Kasus: UIN Sumatera Utara Medan)," J. Ilmu Komput. dan Inform., vol. 3, no. 1, pp. 1-9, 2018.

[6] E. Maiyana, "Pemanfaatan Android Dalam Perancangan Aplikasi Kumpulan Doa," J. Sains dan Inform., vol. 4, no. 1, pp. 54-65, 2018, doi: 10.22216/jsi.v4i1.3409.

[7] R. Kurniawati, "Pengembangan Sistem Informasi Kependudukan Berbasis Mobile Dan Restful Web Service," Semin. Nas. Teknol. Inf. dan Komun., 2016.

[8] H. Setiani and R. D. Gunawan, "Rancang Bangun Sistem Informasi Pendaftaran Kartu Tanda Penduduk Elektronik ( E - Ktp ) Berbasis Web ( Study Kasus : Kecamatan Gadingrejo ) Design of Information System for Registration of Web - Based Electronic Signing Card ( E - Ktp ) ( Case Study : Kec," vol. 7, no. 3, pp. 287-300, 2019.

[9] N. Syabandhi and A. Mulyani, "Pengembangan Aplikasi Pelayanan Administrasi Kependudukan di Kantor Kelurahan Pataruman Kabupaten Garut," J. Algoritm., vol. 13, no. 1, pp. 70-77, 2016, doi: 10.33364/algoritma/v.13-1.70.

[10] S. Silestian, S. Sarkum, and I. Purnama, "Aplikasi Formulir KTP Di Kantor Camat Rantau Utara Berbasis Android," vol. 18, no. 1, pp. 1-10, 2019.

[11] K. Kawano, Y. Umemura, and Y. Kano, “ Field Assessment and Inheritance of Cassava Resistance to Superelongation Disease 1 ," Crop Sci., vol. 23, no. 2, pp. 201-205, 1983, doi: 10.2135/cropsci1983.0011183x002300020002x.

[12] M. Sutedi; Agarina, "Implementasi Rational Unified Process Dalam Rancang Bangun Sistem Informasi Penjualan Hasil Bumi Berbasis Web Pada Cv. Aneka Mandiri Lestari Bandar Lampung," J. Sist. Inf. dan Telemat., vol. 8, no. 2, pp. 181-187, 2017. 